\title{
УДК 37:004:316.772.5
}

\section{Пінчук Ольга Павлівна}

кандидат педагогічних наук, старший науковий співробітник, заступник директора з науково-експериментальної роботи

Інститут інформаційних технологій і засобів навчання НАПН України, м. Київ, Україна ORCID ID 0000-0002-2770-0838

opinchuk100@gmail.com

\author{
Литвинова Світлана Григорівна \\ доктор педагогічних наук, старший науковий співробітник, \\ завідувач відділу технологій відкритого навчального середовища \\ Інститут інформаційних технологій і засобів навчання НАПН України, м. Київ, Україна \\ ORCID ID 0000-0002-5450-6635 \\ s.h.lytvynova@gmail.com

\section{Буров Олександр Юрійович} \\ доктор технічних наук, провідний науковий співробітник \\ Інститут інформаційних технологій і засобів навчання НАПН України, м. Київ, Україна \\ ORCID ID 0000-0003-0733-1120 \\ ayb@iitlt.gov.ua
}

\section{СИНТЕТИЧНЕ НАВЧАЛЬНЕ СЕРЕДОВИЩЕ - КРОК ДО НОВОЇ ОСВІТИ}

\begin{abstract}
Анотація. У статті досліджено проблеми впровадження синтетичного навчального середовища в освітянську практику. Проаналізовано сучасні погляди на сутність навчального середовища і його нові форми, що базуються на інформаційно-комунікаційних технологіях. Особливу увагу приділено колу питань, які об'єднуються в англомовній літературі як «синтетичне середовище», що розглядається в двох аспектах - як штучне і як таке, що утворюється завдяки синтезу реального фізичного світу та результатів симуляції та моделювання. Розглянуто питання використання геймифікації та моделювання як когнітивних технологій, а також соціальних мереж як синтетичного середовища соціального розвитку. Робиться висновок щодо набуття синтетичним навчальним середовищем рівня суб'єкта навчання завдяки розширенню його змістового і дидактичного потенціалу, трансформації особистості як здобувача знань у синтезуючий чинник навчального процесу.
\end{abstract}

Ключові слова: синтетичне навчальне середовище; штучні середовища; віртуалізація; навчальна діяльність; симуляція; моделювання; метавсесвіт.

\section{1. ВСТУП}

Протягом останнього сторіччя психологи і дослідники у сфері освіти розробили багато теорій і концепцій для пояснення того, як люди вчаться, інакше кажучи, як вони набувають, організовують і засвоюють знання й уміння. Виникло декілька різних головних напрямків навчання, що базуються на основних положеннях вікової психології і теорії пізнання. Психологічні теорії навчання можуть бути згруповані в кілька основних категорій і відповідних теорій навчання, таких як біхевіористична, асоціативна, когнітивна, конструктивістська і теорія соціального навчання [1]. 3 виникненням і розповсюдженням інформаційно-комунікаційних технологій (IКТ), їх розвитком і проникненням в усі сфери діяльності людини, як наслідок, у 1980-х роках з'явилися потреба і можливість машинного навчання. На відміну від матеріального світу віртуальні світи дозволяють нам рухатись далі і створювати нові світи, що копіюють нашу усвідомлену реальність чи розвивають нашу фантазію, щоб створити фантастичні місця (нові, інноваційні, творчі), використовуючи необмежену кількість відомих і новостворених об'єктів і символів. 
Необхідність у широкому впровадженні інновацій в усіх сферах діяльності й підготовці «провайдерів інновацій» (людей інноваційного способу мислення, яким потрібна відповідна освіта, що відповідає суттєвим змінам в останні роки), а також зміна ролі інформаційно-комунікаційних технологій у житті людини, способах i формах їі діяльності [2] викликані розвитком нових технологій і переходом людства до інформаційного суспільства [3]. Така тенденція змінюе пріоритети суспільства розвиток людського капіталу, формування специфічних умов його функціонування в інформаційному середовищі, упровадження нових форм і засобів навчання, а також їх ресурсів [4], зростання вимог до когнітивних можливостей людини (характер розумової діяльності якої набуває все більше рис операторської праці) та їх контролю [5]. Відповідно змінюються вимоги до навчання і перепідготовки, уміння та готовності переходу до оволодіння новими професіями, які ще не існували під час вибору професії. Таке навчання все частіше потребує використання штучного середовища IКТ, комп’ютерних тренажерів, програмних та апаратних моделей, - які дозволяють «погратися» 3 хімічними реакціями в живих клітинах, «побачити» стійкість-нестійкість біоценозів певного ареалу, практикуватися в експлуатації і ремонті дорогого устаткування, дослідити дію мікрогравітації. Так можна легше зрозуміти складні поняття й швидко застосувати це розуміння до вирішення практичних проблем. Масштабні багатокористувацькі онлайн-ігри, або МБОІ (в англомовній літературі MMOGs), допомагають гравцям розвивати і тренувати набори навичок, близьких до відповідних умінь мислення, планування, навчання, а також технічних навичок, що все більше користуються попитом у освітян і роботодавців [6].

Постановка проблеми. Зміни у формах, методах i засобах освіти супроводжуються переходом від «суб' єкт-об' єктної» до «суб' єкт-суб' єктної» побудови взаємодії у навчальному процесі, змінами в організації навчального середовища пряме спілкування, опосередковане через цифровий простір, змішане, соціальні мережі тощо [2]. Поширюється використання ігрових технологій у навчанні [7], [8]. Виникає необхідність у моделюванні як нових методик, так і поведінки суб'єктів навчальновиховного процесу, що дозволяє розв'язувати пізнавальні задачі не «в класі», а у цифровому середовищі [9]. Наразі зростає необхідність урахування різних аспектів безпеки життєдіяльності особистості, що не обмежуються проблемами фізичної безпеки, а потребують урахування людського чинника в широкому розумінні на різних етапах життя. Фактично життя людини зміщується все більше у синтетичне середовище, а діяльність, спілкування, навчання, дозвілля i, навіть, особисте життя (інформаційне, емоційне, чуттєве) відбувається все більше у віртуальному просторі зі своїми перевагами, недоліками та небезпеками [3].

Аналіз останніх досліджень і публікацій. Оскільки тенденція використання синтетичного середовища в освіті є досить новою, іiі переваги, недоліки та наслідки залишаються непередбачуваними дотепер. Починаючи з 2001 р., проблемою створення i використання синтетичного навчального середовища займалися, насамперед, дослідники у сфері емерджентних технологій, космічної та воєнної сфер [10]. Велика увага приділялась балансуванню технологій, вартості створюваного середовища, довіри йому й оцінюванню його ефективності. В останні роки все більше уваги приділяється аналізу можливостей синтетичного середовища для навчання в цілому [11]. Якщо 10 років тому можливості Second Life (тривимірний віртуальний світ 3 елементами соціальної мережі) розглядалися лише 3 позицій потенційного середовища ігрового характеру, то в останні роки Second Life пропонується як випробуваний ресурс для широкого навчання (Гарвардський та Оксфордський університети) або проведення нарад і налагодження взаємодії співробітників (компанії IBM i Sun Microsystems), a також як віртуальні дослідницькі центри (NASA). Насамперед умови для цього створює 
використання хмарних технологій в освіті [12], а також поширене використання мультимедійних технологій [13], ігор у навчальному і тренувальному процесах [6], у системах моделювання навчання як такого [14]. Проте такі зміни засобів і структури середовища навчання змінюють навчальне навантаження на учня/студента й актуалізують проблему врахування психологічної і психофізіологічної «ціни» навчальної діяльності [15].

Мета статті - аналіз тенденцій побудови й використання синтетичного навчального середовища.

\section{2. МЕТОДИ ДОСЛІДЖЕННЯ}

Під час дослідження використовувались такі методи: пошук релевантної інформації, аналіз загальних тенденцій розвитку навчального середовища, аналіз теоретичних джерел 3 проблем навчального середовища, вивчення й узагальнення сучасних знань щодо проектування i застосування синтетичного навчального середовища. Дослідження виконано в межах НДР «Формування інформаційноосвітнього середовища навчання старшокласників на основі технологій електронних соціальних мереж» (номер державної реєстрації 0115U002232).

\section{3. РЕЗУЛЬТАТИ Й ОБГОВОРЕННЯ}

Ще у 2000 р. Г. Келлі, президент Федерації американських учених, у своїй промові на засіданні секції систем навчання наступного покоління звернув увагу на те, що «перехід до економіки знань відбувається більш швидкими темпами, ніж наша здатність забезпечити необхідними високотехнологічними робітниками, а також безперервне навчання існуючої робочої сили. ... Майже 80\% поточних доходів компаній Fortune 500 є продуктами або послугами, що не існували ще два роки тому, а 50\% знань працівників стають застарілим уже через 3-5 років» [6].

На часі ця проблема ще більше загострилась, вимагаючи впровадження інноваційних технологій не тільки у виробництві, але й у підготовці працівників «економіки знань». Так, за даними Московської школи управління «Сколково», к 2030 р. зникне 67 професій, а в той же час виникнуть 188 нових професій, невідомих нині.

Можна погодитись 3 формулюванням основного принципу інноваційного розвитку навчального середовища (HC) як зміни стану НС на підставі прийняття рішення щодо проектування нових властивостей фахівця-освітянина в результаті отриманої інформації щодо стану ринку професійних компетенцій. I визначальними для такого рішення можуть бути очікувані риси нового, VI технологічного укладу: нано- та біотехнології, робототехніка та когнітивні технології, які дозволять створити нову медицину, нове природокористування, забезпечити безпеку техносфери, альтернативні види енергетики тощо. Усі ці галузі мають спільність в тому, що є наукомісткими, тобто високими технологіями, проблеми розвитку яких безпосередньо пов'язані, а часто і визначені можливостями інформаційно-комунікаційних технологій.

Як указують результати дослідження Brandon Hall Group 3 тенденцій змін у навчальних технологіях 2016 р. (насамперед, у сфері eLearning), хмари, соціальні інструменти, мобільні технології та інші досягнення створили безліч можливостей для нового досвіду навчання настільки, що технологія стала найвищим пріоритетом 3 питань навчання та розвитку. Вивчення нових і різних технологій (за оцінками 48\% серед опитаних представників 302 організацій) перевершило за значенням навіть 
стратегію навчання (47\%) як головний фокус на найближчі 12 місяців [16]. Третім (за рангом) пріоритетом $є$ створення більш тісного зв'язку між навчанням i продуктивністю професійної діяльності. Найкращими шляхами для освоєння технологій є інструменти соціальної взаємодії і спільної роботи (43\% респондентів), а також мобільного доступу (41\%). Проте, як відзначають автори дослідження, задоволення від використання цих інструментів залишається низьким через недостатній досвід користувачів та адміністраторів ресурсів. Критичного значення набувають управління талантами (36\% у структурі інтеграції в корпоративну систему) та управління трудовими ресурсами (27\%), тоді як вибір платформи і технічних засобів $\epsilon$ критичним тільки на $20 \%$ і менше.

Наведені та інші відомі дані свідчать про тенденцію до перенесення навчальнорозвивальної діяльності у синтетичне середовище, де зміст навчання зміщується в бік самонавчання і проектно-орієнтованої діяльності. Таке навчальне середовище має нові риси, що не залишаться незмінними навіть у найближчому майбутньому, розвиваючись за певними законами, які доцільно дослідитиі спробувати передбачити. На нашу думку, ефекти інноваційного реформування освіти можна очікувати саме в цій сфері.

Наше дослідження ролі синтетичного навчального середовища проведено у таких напрямах: навчальне середовище $(\mathrm{HC})$ - визначення, види; синтетичне навчальне середовище (СиНС) - погляди й підходи; ігро-орієнтоване навчання; хмаро орієнтоване, змішане, синтезоване гібридне НС; оцінювання ефективності СиНС.

\section{1. Види навчального середовища - понятійний апарат}

Незважаючи на давню історію застосування поняття «навчальне середовище» та визнання його ролі в навчанні (починаючи з Ж.-Ж. Руссо, який одним з перших почав розглядати середовище як поле для розвитку особистості і вважав за необхідне створення особливого «освітнього середовища» 3 метою врівноваження потреб i можливостей учня), дотепер існують різні погляди на роль і розуміння сутності середовища навчання, тобто у різних фахівців немає єдиної позиції в його визначенні, у розумінні структури навчального середовища, його функцій, методів проектування та експертизи.

Різні автори розрізняють природні і штучні, предметні й інформаційно-динамічні, адаптивні та інші навчальні середовища. Існують різні критерії типологізації освітніх середовищ (у дужках наведені приклади різних шкал з полярними значеннями на них):

- за стилем взаємодії всередині середовища (конкурентне-кооперативне, гуманістичне-технократичне, суб'єкт-об'єктне);

- за характером відношення до соціального досвіду і його передачі (традиційнеінноваційне, моноетнічне-універсальне тощо);

- за ступенем творчої активності (творче-регламентоване);

- за характером взаємодії із зовнішнім середовищем (відкрите-замкнуте).

Необхідно відзначити, що будь-яка типологія освітнього середовища умовна i залежить від соціально-економічного базису освіти. Так, наприклад, класичною $є$ класифікація Я. Корчака (1919р.), який пропонував чотири типи виховного середовища: «догматичний», «ідейний», «безтурботного споживання» та «зовнішнього лиску і кар'єри». Проте глобальні процеси останніх десятиліть та перехід людства до інформаційної ери внесли свої корективи в цю типологію.

Серед найбільш прийнятних сучасних визначень НС, на нашу думку, слід вказати подані далі. 
Севенков О. І.: «система педагогічних і психологічних умов i впливів, які створюють можливість для розкриття як вже наявних здібностей і особистісних особливостей учнів, так і тих, що ще не проявилися, інтересів і здібностей» $[17$, с. 5];

Гущина Т. М.: «засіб розвитку суб'єктності старшокласника, яку він реалізує в ході діалогової взаємодії, орієнтації на інших суб'єктів діяльності та спілкування. Педагогічний зміст навчального середовища визначають його ключові функції, які можна позначити наступним чином: розвиток, вибір цінностей, регуляція, безпека, фасилітує взаємодію» [18, с. 189];

Биков В. Ю.: «штучно побудована система, структура і складові якої сприяють досягненню цілей навчально-виховного процесу. Структура НС визначає його внутрішню організацію, взаємозв'язок і взаємозалежність між його елементами» [19, c. 4].

Перехід людства до інформаційної ери супроводжується появою нових аспектів навчального середовища, які набувають стрімкого розвитку та можливостей.

Насамперед слід відзначити зростання ролі відкритого комп'ютерно орієнтованого навчального середовища, під яким мається на увазі ІКТ-навчальне середовище педагогічних систем, у якому окремі дидактичні функції передбачають педагогічно доцільне використання комп'ютерних і комп'ютерно орієнтованих засобів навчання й електронних освітніх ресурсів, що входять до складу ІКТ-системи навчального закладу, а також засобів, ресурсів і сервісів відкритих інформаційнокомунікаційних мереж (Інтернет) [4, с. 12].

Згідно до Дж. Кенон-Боуерс і К. Боуерс, швидко зростає роль синтетичного навчального середовища, тобто середовища навчання, що характеризується 3 точки зору тієї чи іншої технології, предмета, характеристик учня та педагогічних принципів. Синтетичний досвід взаємодії з реальним пристроєм або процесом, створюється через моделювання, ігри або іншу технологію [20]. При цьому синтетичне середовище є реконструйованим багатофункціональним середовищем iз сумішшю реальних i комп'ютерних синтезованих (модельованих) об'єктів під управлінням комп'ютера, який забезпечує взаємодію між комбінаціями реальних і синтезованих об'єктів.

Синтетичне середовище (СиС) складається з цифрового й аналогового уявлення фізичного середовища із заданою точністю і складністю та масштабується до будьякого розміру і ступеня складності. Згідно до позиції IT Law Wiki, СиC включає будьякі з поданих систем (див. http://itlaw.wikia.com/wiki/The_IT_Law_Wiki) :

- телеоператорні системи;

- системи віртуального середовища;

- системи доповненої реальності.

Насамперед розвиток і класифікація СиС проводились для виробничих систем i, перш за все, для складних людино-технічних систем, де людська ланка представлена людиною-оператором. У сучасному (і майбутньому) навчальному середовищі суб' єкт навчального процесу фактично функціонує як оператор, використовуючи для досягнення кінцевої мети (набуття знань, умінь, компетентностей) допоміжні проміжні засоби (технічні, інформаційні, організаційні тощо). Відповідно, на часі корисним $\epsilon$ урахування поглядів IT Law Wiki як певного узагальнення підходів до СиС: «У системі синтетичного середовища (СиС) людина-оператор переноситься до нового інтерактивного середовища за допомогою пристроїв, що відображають сигнали в сенсорні органи людини та пристрої, які сприймають різні дії оператора». Дотепер зусилля у дослідженнях і розробці, що безпосередньо стосуються створення корисних СиС, мають відношення до:

1) комп’ютерного генерування віртуальних середовищ;

2) проектування дистанційно керованих роботів; 
3) вдосконалення інтерфейсу людина-машина;

4) вивчення відповідних аспектів поведінки людини;

5) розроблення комунікаційних систем, що забезпечують підтримку мереж СиС.

Ми погоджуємося 3 авторами IT Law Wiki peсурсу, що у наш час «сфери застосування, що заслуговують уваги, включають: 1) розваги, 2) національну безпеку, 3) проектування, виробництво та маркетинг, 4) медицину й охорону здоров'я, 5) небезпечні операції, 6) підготовка, 7) освіта, 8) візуалізація інформації, 9) телекомунікації та телеподорожі». Розширення сфери застосування СиС на освіту має значні перспективи, особливо завдяки сформованості засобів освіти на основі ІКТ і досвіду використання мультимедійних засобів і мультимедійних технологій. Загальновизнаним $\epsilon$ те, що останні розширюють когнітивні можливості учня.

Оскільки навчання можна вважати конструюванням знань, Р. Мейер доводить на фактичному матеріалі, що навчання із застосуванням аудіо- і візуальної інформації значно продуктивніше для отримання знань, ніж тільки із застосуванням словесної форми навчального матеріалу. На лекції, прочитаній ним у Гарвардському університеті в травні 2014 р., наведені результати виконання студентами тесту на розуміння матеріалу, що показують суттєву різницю у правильному відтворенні навчального матеріалу: у середньому 30\% при використанні нарративної або текстової інформації, 45\% при використанні текстів + ілюстрацій, 55\% при використанні нарративу + анімації [21]. Проте важливим $є$ оптимальне використання візуального навантаження. Автор визначає 3 top-level мети проектування мультимедійного навчального середовища (МмНС): 1) зменшити оброблення побічної інформації, 2) керувати суттєвим обробленням, 3) сприяти продукуючій обробці. Відповідно, він рекомендує використовувати подані нижчені принципи проектування МмНС.

П’ять принщипів зменшення побічного оброблення.

1. Принцип узгодженості.

2. Принцип сигналізації.

3. Принцип резервування.

4. Принцип просторової суміжності.

5. Принцип тимчасової сугестії.

Три принциии управління суттєвим обробленням.

1. Принцип сегментації.

2. Попередня підготовка.

3. Принцип модальності.

Два принщиипи сприяння генеративній обробщ̧і.

1. Принцип персоналізації.

2. Голосовий принцип (озвучування людським голосом, а не синтезованим машинним).

Певною мірою можна вважати використання МмНС перехідним кроком до навчання в СиС, а принципи його побудови справедливими для останнього.

Слід наголосити, що саме 3 поняттям СиС пов'язано поняття імерсивного та віртуального середовища.

На думку С. Ф. Сергеєва, навчальне середовище у змістовому плані виникає завжди як динамічний процес формування мережі відносин у суб'єкті навчання, до якого (не завжди усвідомлено) вибірково залучаються найрізноманітніші елементи зовнішнього та/або внутрішнього оточення 3 метою забезпечення: аутопоезиса організму, стабільності особистості та безперервності іiі історії [22]. До основних властивостей імерсивного навчального середовища можна віднести: надмірність, можливість спостереження, доступність когнітивному досвіду, насиченість, пластичність. позасуб'єктна просторова локалізація, автономність існування, 
можливість синхронізації, векторність, цілісність, мотивогенність, імерсивність, присутність, інтерактивність.

Найпоширенішим $є$ визначення віртуального навчального середовища $\mathrm{y}$ Wikipedia: «Віртуальне навчальне середовище (ВНС) (англ. virtual learning environment (VLE) - програмна система, створена для підтримки процесу дистанційного навчання 3 наголосом саме на навчання, на відміну від керованого навчального середовища, для якого властивий акцент на управлінні процесом навчання» (див. https://uk.wikipedia.org/w/index.php?title=Віртуальне_навчальне_середовище\&oldid=178 61371). «ВНС зазвичай використовує мережу Інтернет і надає засоби для оцінки (зокрема, автоматичної оцінки, наприклад, завдання на вибір), комунікації, закачування матеріалів, повернення робіт студентів, оцінювання колег, управління групами студентів, збирання та організація оцінок студентів, опитування тощо. Серед найновіших особливостей $\mathrm{BHC}$ - широке запровадження технологій wiki, блогів та RSS. Ідеологія ВНС базується на об'єктно-орієнтованому підході до навчання, для якого властиве використання різноманітних навчальних об'єктів».

Імерсивне (тобто таке, що викликає занурення у процес) середовище у віртуальній реальності передбачає досягнення стану свідомості, при якому суб'єкт сприймає себе присутнім фізично у нефізичному (віртуальному) світі. При цьому відчуття фізичного стану зменшується або втрачається зовсім. Слід зауважити, що будь-яке ефективне НС повинно бути певною мірою імерсивним, створюючи в учня ефект захоплення, «занурення». 3 цієї точки зору імерсивність притаманна не лише СиНС, проте остання набуває особливого значення, оскільки, по-перше, у синтетичному середовищі з'являються нові можливості для когнітивної діяльності, а по-друге, постійно зростає спектр навчального інструментарію. Синтетичні засоби навчання починають конкурувати один з одним, що дозволяє учню обирати саме ті, які відповідають його індивідуальним можливостям і вподобанням.

Найчастіше імерсивне HC асоціюють із Second Life, проте на часі з'являється все більше глобальних i локальних інструментів, що відповідають зазначеним характеристикам. За експертними даними, на сьогодні вже існують сотні подібних розробок, у яких зареєстровані сотні тисяч користувачів, які діють (навчаються, працюють) у синтетичному світі.

Найбільш загальними перевагами імерсивного СиНС, $\epsilon$ такі: усунення необхідного компромісу між експериментальними і реальними умовами, керування точністю відтворення реальної ситуації, забезпечення ненав'язливих вимірювань, створення платформи раніше (у звичайних умовах) неможливих або дуже складних маніпуляцій та управління.

\section{2. Синтетичні світи й освіта}

Поширеність терміна «синтетичне навчальне середовище» (СиНС) в англомовній літературі пов'язана з появою і стрімким розвитком електронних засобів навчання, що створюють нові можливості для освіти, розвитку та нових форм соціалізації людини. різні підходи до розуміння «синтетичності» навчального середовища, місця та «присутності» суб' єктів НС у навчальному процесі.

Так, позиціонування концепції «присутності», у першу чергу, у соціальному інтерактивному контексті знаходить розвиток у економіста Е. Кастранова, який у центр уваги ставить соціальну природу онлайн синтетичних світів. Тобто засіб «соціальної присутності», як, вважає дослідник, є одним із найважливіших факторів, що сприяють почуттю радості та задоволення. Занурення у ці світи дає їх мешканцям: емоційні соціальні взаємодії та можливість поділитися успіхами; формування тісних зв'язків і 
спонукань, широкі групи і союзи однолітків; пам'ятки соціального дискурсу; спільні спогади і досвід, удосконалення, що забезпечує соціальний світ онлайн-ігор більше, ніж відеоігри. Схильність соціального фактора до онлайн «присутності» призводить до того, що всі розробники комп'ютерних ігор планують поставляти в найближчому майбутньому свої онлайн-консолі одразу в Інтернеті [23].

На часі здається, що освітня діяльність в метавсесвіті (metaverse) в цілому, як це проявилося у віртуальних розширеннях більшості навчальних інституцій в Second Life, зазвичай, розглядається як просто продовження навчання реального життя у класі в новому середовищі, із завданнями і методологією навчання, що тісно поєднують в собі те, що відбувається у традиційному навчальному середовищі, а віртуальний клас, у якому відбувається навчальна діяльність, є дуже близькою адаптацією або навіть точною реплікацією реального. Проте проблема полягає в адаптації і зміні навчального змісту і стратегії навчання з урахуванням можливостей штучного середовища, оскільки саме виникнення метавсесвіту (як розширення реального світу, у якому доступні вимірюванню фізичні параметри, за рахунок інформаційного й уявного, інформаційноенергетичного, світу людини) ставить нові вимоги до людини i, у той же час, надає їй нові можливості свого когнітивного розвитку.

Дж. Кенон-Боуерс і К. Боуерс вважають, що в багатьох випадках синтетичні навчальні середовища передбачають комп'ютерне моделювання як центральний компонент i, таким чином, виступають як навчання на основі симуляції і моделювання [20]. На думку авторів, синтетичні навчальні середовища можуть бути розроблені нескінченою кількістю шляхів і тому вимагають врахування багатьох змінних. Тому розробка синтетичного навчального середовища висуває додаткові вимоги до педагогічного проектування. Автори зосереджують увагу на декількох навчальних функціях і стратегіях, таких як автентичність і наявність навчального досвіду, обгрунтування на основі використання моделей, розробка ситуацій або сценаріїв, які забезпечують контекст навчання, спільне і соціальне навчання, а також різні мотиваційні фактори (наприклад, встановлення цілей, залучення, підкріплення).

3 поняттям «синтетичний світ» зв'язано поняття «синтетичного досвіду», яке охоплює віртуальні середовища, телепередачі, використання шоломів віртуальної реальності (Head-Mounted Display, HMD), фільми, телефон, відеоігри. Він є синонімом терміну, що використовувався раніше - технологічно-опосередкований досвід. Проте багато дослідників у цій сфері обмежують сферу синтетичного досвіду відтворенням чуттєвого досвіду, що більше відповідає концепції синтезу діяльності людини та техніки.

Слід зауважити, що нові пристрої, які містять HMD, не є чимось принципово новим, а $€$ розширенням і вдосконаленням попередніх засобів, пристроїв і носіїв інформації. Засоби відображення інформації почали розвиватися ще у той час, коли доісторична людина створила візуальні уявлення про світ, використовуючи малюнки. За живописом виникли телескоп, мікроскоп, фотозйомка, фонограф, телефон, кінематограф, телебачення та відеоігри. Кожне 3 цих технічних рішень надає можливість записувати, змінювати або передавати певні аспекти сприйняття світу людиною, посилюють можливості іï сенсорних систем. 3 такої точки зору HMD $\epsilon$ черговим кроком на цьому еволюційному шляху і набуває значення не тільки техніки візуального відображення, а й технології багатостороннього відображення 3 візуальними, вестибулярними та проприоцептивними системами, у якій створюються візуальні зображення, що відбивають навколишній багатовимірний світ так, щоб відповідати природним рухам голови користувача.

В останні роки активно 3'являються все нові й нові засоби використання HMD: моделювання польотів, окуляри нічного бачення, мікро-телепередачі, додана 
реальність. Декілька попередніх років великі сподівання покладалися на окуляри Google Glass. У 2014 р. всесвітньо відомий фізик і популяризатор науки, професор М. Каку, вважав, що у найближчому майбутньому завдяки ним не потрібно буде перевантажувати мозок «безкорисними» знаннями, основний відсоток яких у подальшому не використовується. Звільнений розумовий резерв можна буде переорієнтувати на розвиток здатності думати, аналізувати, аргументувати та приймати правильні рішення. Зараз останньою технологічною новинкою на цьому шляху, що набуває стрімкої популярності завдяки новим можливостям і доступності, є HoloLens, запропоновані компанією Microsoft. У цих гаджетах закладена можливість контролю стану параметрів діяльності користувача, що значно розширює можливості як індивідуалізації навчального простору, так і симуляції нових середовищ і синтетичних світів із вбудовуванням у них суб'єктів симуляції більш наближених до живих.

Багато хто 3 дослідників розуміє синтетичний досвід як природний досвід, розширений за допомогою спеціальних технологічних засобів, що призначені, як правило, для занурення людини у представлення дійсності. Ця дійсність сприймається нею як занурення або в завдання, або стан розуму, або уявний простір, або їх поєднання. При обробці реальності людська система сприйняття поширюється також всередину, на внутрішній світ, до образів мислення, де структура тіла, тобто сама сенсорна система, моделює організацію ідей та взаємодії. Тому синтетичний досвід має унікальний потенціал для взаємодії зі структурами розуму та набуває функцій своєрідного екзоскелета мислення [24].

Нові техніко-технологічні рішення для створення СиНС вимагають розвитку педагогічних систем та їх методологічних засад. Так, К. Олдріч вважає, що педагогіка $є$ одним із шести «критичних критеріїв», які потребують уваги, якщо ми хочемо підвищити якість синтетичного середовища [25]. На думку автора, основні педагогічні елементи в СиНС мають включати:

- надання достатньої довідкової інформації/ресурсів, вбудованих в симуляцію;

- підготовка навчальних налаштувань;

- діагностичні взаємодії;

- співпраця;

- динамічна і контекстно-сензитивна допомога;

- впроваджені рефлексивні стратегії;

- досвід роботи;

- контрольований студентом досвід.

Можливості методик активного навчання та СиНС мають певний паралелізм, але із своєю специфікою:

\begin{tabular}{l|l} 
Властивості активного методу навчання & Властивості СиНС: \\
\hline активна співпраця & спільне навчання \\
\hline активна взаємодія & занурення \\
\hline мотивування & самомотивація \\
\hline взаємодія з середовищем & розширені можливості вибору \\
\hline публікація знань & конструювання середовища \\
\hline трансфер знань & конструювання об’єкта \\
\hline передавання особистого досвіду & наполегливість \\
\hline навчання вчитися & пошук власного шляху \\
\hline адаптивність & самоконтроль \\
\hline контроль знань & гнучкість
\end{tabular}


Утім, творче впровадження нових, штучних, світів дозволяє отримувати нові можливості для вивчення просторів, де учні мають лише системні обмеження та можуть застосовувати різні медійні засоби «для реалізації свого контенту та експериментування з ідеями без ризику» [17, с. 6]. Використання віртуальних світів у контексті навчання «демонструє можливості взаємозв'язаних та масштабованих показників часу, процесів та децентралізованого доступу до Інтернету». Фактично таке експериментування з використанням моделювання та симуляції є різновидом ігрової діяльності з більш високим когнітивним навантаженням. Слід зауважити, що ігри стають дедалі складнішими і можуть 3 успіхом використовуватися у навчальнопізнавальній діяльності.

\section{3. Ігро-орієнтоване навчання і моделювання як когнітивні технології}

Піонер у дослідженні гри і засновник Національного інституту гри США С. Браун стверджує, що гумор, ігри, буйства, флірт і фантазії - це більше, ніж забави. У своїй відомій книжці «Гра: як вона формує мозок, відкриває уявлення та збуджує душу» він пояснює, як у цілій низці наукових дисциплін доводиться важливість гри протягом життя [26]. Грайливість посилює нашу здатність до інновацій та адаптації до мінливих обставин. «Дорослі, позбавлені гри, часто є жорсткими, негнучкими і закритими до спроб нових варіантів. Гра - це активний процес, який змінює наші жорсткі погляди на світ». Розширення можливостей використання IКТ, їх доступності для різних верств населення, загальне зростання комп'ютерної грамотності, а також розвиток медійних й інтелектуальних можливостей засобів доступу людини до Інтернет суттєво розширюють ігровий потенціал пізнання світу, а також можливості людини у віковому та когнітивному аспекті. С. Браун впевнений, що гра (особливо у цифровому вигляді) стає наріжним каменем педагогіки для освіти у 21-у столітті. Завдяки використанню моделей ігро-орієнтованого навчання майбутні працівники (насамперед, у сфері індустрії знань) готуються до швидкого реагування на зміни техніки і технологій, зміни професії і кар'єри. Успіх складних відеоігор демонструє, що ігри можуть сприяти розвитку стратегічного мислення, інтерпретаційного аналізу, здатності до вирішення проблем, формулювання та виконання плану, а також адаптації до швидких змін. А на сьогоднішньому ринку праці саме ці навички мають найбільший попит серед роботодавців.

Як зазначалось на Національному саміті $з$ освітніх ігор (25 жовтня 2005 р., Вашингтон, США), «... ігри та симулятори можуть також слугувати потужними практичними інструментами для навчання практичним та технічним навичкам, від автомобільного ремонту до хірургії серця. Крім того, сьогоднішні студенти, які зростають використовуючи цифрові технології та відеоігри, найбільш готові скористатися можливостями ігро-орієнтованої освіти» [27]. Дотепер програма Федерації американських учених FAS Learning Technologies Program зосереджена на іграх та інших технологіях, що і навчають «передовим абстрактним поняттям». Те, що здається занадто абстрактним для навчання школярів, художниками та дизайнерами ігор подається у вигляді ігор. Як стверджують експерти FAS, «Білки та їх групи можуть стати такими ж знайомими, як зомбі і рушниці. Ми намагаємося продемонструвати, що взаємодію між молекулами, поведінку мікроскопічних та наноскопічних об' єктів, а також дії клітин у відповідь на зміну їх оточення можна викладати у форматі відеоігор» (див. https://fas.org/programs/ltp/). Тим самим поєднуються комп'ютерно орієнтовані технології навчання та ігри у відповідності до загальних тенденцій сучасного розвитку технологій [3, с. 21]. Серед іншого, навчальні ігри і симулятори забезпечують: формування практичних навичок; навчання людей для виконання високопрофесійної 
діяльності, що вимагає складних рішень; зміцнення навичок, що рідко використовуються; передачу досвіду того, як фахівці підходять до вирішення проблем; створенню команди.

Слід зауважити, що деякі експерти приділяють особливу увагу тому, що існують відмінності між іграми для навчання й іграми для розваг. Розробники освітньої гри повинні бути націленими, перш за все, на бажаний навчальний результат, а потім спроектувати гру для досягнення цієї мети. Освітні ігри повинні будуватися на основі науки про навчання.

C кілька атрибутів ігор, що можуть бути корисними для застосування у навчанні:

- контекстна взаємозалежність (тобто ліквідація розриву між тим, що вивчається теоретично, та його використанням);

- достатній час на робочому місці;

- мотивація та цільова орієнтація, навіть після невдачі;

- надання учням підказки, рекомендацій та часткового рішення, що дозволять розвиватися шляхом навчання;

- персоналізація навчання;

- нескінченне терпіння.

У цілому стверджується, що створення, комерціалізація та прийняття ігор для навчання $\epsilon$ багатопрофільним інноваційним завданням - залученням наукових відкриттів i технічного прогресу, креативного дизайну i розвитку, дружнього інвестиційного клімату, змін у педагогіці та нових ролях для вчителів і учні [27, с. 7].

У 2014 році було завершено багаторічне дослідження адаптивного навчання для розробки навчальних ігор [28]. У результаті було розроблено і затверджено модель ALGAE (Adaptive Learning GAme dEsign) - адаптивну модель навчання, засновану на теоріях і практиці дизайну ігор, навчальних стратегій та адаптивних моделей. Практичним результатом дослідження було створення адаптивної моделі моделювання навчальних ігор для дітей, що слугувала б керівництвом для дизайнерів ігор, дизайнерів-інструкторів та педагогів 3 метою підвищення результативності навчання. Ця модель тепер слугує керівним принципом для проектування і розробки освітніх комп'ютерних ігор.

3 метою зближення навчання й отримання необхідних професійних умінь дослідниками 3 університету Делфт у Нідерландах запропоновано концепцію Microgames як активного, ситуативно-орієнтованого навчального підходу. Microgame це симуляційна гра, яку можна відтворити за короткий проміжок часу і яка починається з певної проблеми в організації, що визначена керівництвом. Компенсувати обмеження гри у часі дозволяє структурований етап роз'яснення й обмін гравців інформацією про успішні стратегії планування, посилюючи досвід навчання за допомогою соціальної взаємодії.

Фактично СиНС є навчальними системами, вбудованими у віртуальні світи. Відповідно, симуляція і моделювання в сучасних ІКТ наближаються й набувають усе більше рис ігрової діяльності із зануренням у проблему, а завдяки засобам доданої реальності в синтетичному навчальному середовищі значно розширюють можливості навчання та когнітивного розвитку учнів.

Слід зазначити, що вже впродовж кількох десятиліть моделювання є одним 3 найбільш актуальних методів наукового дослідження i широко застосовується в педагогічних пошуках. Метод моделювання дає можливість об'єднати емпіричне i теоретичне в педагогічному дослідженні - поєднувати в ході вивчення педагогічного об'єкта експеримент, побудову логічних конструкцій і наукових абстракцій. У той же час нові можливості СиНС дозволяють розширити навчально-методичний інструментарій освіти за рахунок уведення в навчальний процес не тільки 
моделювання, але й симуляції, яка, зазвичай, включає відтворення певних ключових властивостей чи функціонування досліджуваного фізичного або абстрактного об'єкта, а деталізовані експерименти неможливі через його складність, небезпеку або високу вартість.

\section{4. Електронні соціальні мережі як синтетичне середовище соціального розвитку}

Використання електронних соціальних мереж у навчально-наукових цілях обумовлено історично. Як відомо, всесвітньо популярний ресурс Facebook з'явився як академічна соціальна мережа. Спочатку веб-сайт був доступний тільки для студентів та працівників Гарвардського університету, а потім був зареєстрований для інших університетів Бостона, пізніше і для студентів будь-яких навчальних закладів США, що мають електронну адресу в домені .edu. Одними з перших користувачів соціальної мережі Twitter також були американські вчені. У рамках першого року існування в ньому переважали повідомлення про наукові конференції, симпозіуми, посилання на наукові роботи тощо і лише пізніше він став популярним для всіх професій і верств населення планети. Аналіз іншомовних науково-дослідних та освітніх публікацій дозволяє стверджувати, що зарубіжні дослідники бачать в електронних соціальних мережах (ECM) механізм подальшого розвитку науки й освіти.

Головна відмінність сучасних ЕСМ полягає в тому, що мережі мають особливий потенціал для соціалізації учнів. Якщо традиційне вчення спрямоване на передачу певних знань і розвиток інтелекту, що перетворює інформацію, то цифровий простір (насамперед соціальні мережі) може також розвивати соціальний і культурний інтелект відповідно до сучасних тенденцій у потребах дітей. Кожен вид інтелекту сприяє інтегральному «успішному розуму» (за Р. Стернбергом), але відповідає конкретному різновиду відносин людини із зовнішнім світом [29]. Причому можливості реалізації соціальних уподобань людини практично не обмежена, хоча, як і будь-який соціум, ЕСМ переходять у стан самоорганізації і саморегуляції. Відповідно, виникають нові види і методи регуляції обмежень, які $\epsilon$ можливість перевірити за допомогою моделювання і симуляції у синтетичному середовищі. Фактично ЕСМ і є синтетичним середовищем соціального і культурного розвитку особистості, де виникають свої особливі правила, норми та культура спілкування. Попри це, виникають (і можуть бути контрольованими) широкі спільноти, які в реальному житті й суспільстві можуть не існувати.

Моделюванню соціальних процесів може сприяти те, що попри те, що мультифункціональність і соціабельність ЕСМ сприяють мобільності соціального капіталу, усередині самих ЕСМ народжуються ціннісні імперативи. Так, важливе місце в процесі функціонування ЕСМ відіграє «мережний етикет», який гарантує, що кордони віртуального співтовариства знаходяться під контролем. В управлінні соціальними акторами виникає проблема саморегуляції соціальної мережі, що у своїй основі містить нове розуміння свободи, відповідальності, ідентичності» [29].

Одним із сучасних трендів досягнення успіху в бізнесі є процес спільної діяльності в інтелектуальній сфері окремих людей або організацій для досягнення спільних цілей, за якого відбувається обмін знаннями, навчання i, так зване, досягнення згоди. Якщо колаборативне навчання (навчання у співпраці, у спільній роботі) сприймається як деяка теорія взаємодії в навчальному процесі, визначення загального його спрямування, то кооперативне навчання є засобом реалізації колаборації.

Колаборативне навчання включає такі формати як групові проекти, спільні розробки тощо. У контексті електронного навчання колаборативне навчання отримало 
нове трактування (computer-supported collaborative learning). Його, у першу чергу, пов'язують 3 використанням сервісів веб 2.0, соціальних мереж, програм, що підтримують сумісну діяльність віртуальних спільнот із метою навчання.

Кооперативне навчання орієнтоване на використання кількісних методів, які враховують досягнення - результати навчання. Кооперативне навчання $\epsilon$ структурованою, систематичною навчальною стратегією, за якої малі цілеспрямовано відібрані групи в 3-5 учнів працюють разом над спільною метою, створюючи наразі певний кінцевий продукт, що володіє змістовою конкретністю. Кожен учень індивідуально відповідає за результати своєї роботи, а вчитель виступає в ролі консультанта процесу групового навчання. Усі учні в групі несуть відповідальність за роботу (немає лідера). Кооперативна робота в групі охоплює як успішне просування в пізнавальному процесі кожного учня, так і зав’язування, і підтримку хороших робочих стосунків між членами групи. Для успішної кооперативної роботи необхідна ціла низка соціальних навичок: уміння слухати, поважати думку опонента, висловлювати критику з метою виправлення помилок.

В умовах глобалізації й інтенсивного розвитку інформаційних технологій електронні соціальні мережі (ЕСМ) стають симбіозом соціальної та технічної реальності, що утворює різноманітні комунікативні конфігурації (просторово-часові, суб'єкт-суб'єктні, суб'єкт-об'єктні), які компенсують високу інформаційну щільність сучасного суспільства і здійснюють всі види соціальної комунікації (масової, міжособистісної, групової) на всіх технологічних рівнях: вербальному, письмовому, аудіовізуальному.

Створюючи «навчальні ситуації», орієнтовні на використання ЕСМ, учитель може сприяти формуванню універсальних навчальних дій (особистісних, регулятивних, пізнавальних, комунікативних), які забезпечать розвиток здібностей самостійного засвоєння нових знань й умінь, формування і розвиток критичного мислення, розвиток комунікативних умінь школярів. Форма навчання передбачає конструювання конкретних форм, які забезпечуватимуть умови для ефективної навчальної роботи учнів під керівництвом педагога й реалізується як єдність змісту і технологій навчання, результатом якої є засвоєння суб'єктами навчання знань, умінь, навичок і розвиток як предметних, так і ключових компетентностей. Причому ці форми є загальними, але можуть обиратися адаптивно для учнів різних можливостей i віку, забезпечуючи доступ до навчання протягом життя [30].

\section{4. ВИСНОВКИ ТА ПЕРСПЕКТИВИ ПОДАЛЬШИХ ДОСЛІДЖЕНЬ}

1. У XXI ст. освітній простір набуває нових рис з посиленням ролі синтетичного навчального середовища.

2. Синтетичне навчальне середовище стає самостійним суб'єктом навчання завдяки розширенню його змістовного і дидактичного потенціалу, активної участі (пропозиції, надання можливостей вибору та полілогу, «занурення», можливість адаптування навчального процесу під потреби та можливості учня тощо) у формуванні компетентності учня, а також можливості його соціалізації.

3. Трансформація особистості як носія (здобувача) знань у синтезуючий складник навчального процесу, коли когнітивні потреби й можливості розвиваються шляхом сприйняття і переробки інформації від обох зовнішніх світів (реального фізичного й інформаційного синтетичного), а також внутрішнього (біологічного) «світу», які мають i можуть бути гармонізовані (заради здоров'я учня) шляхом вибору траєкторії та необхідних ресурсів навчання, а також індивідуальної адаптації учня. 
4. Учень-особистість створює свій особистий полімодальний навчальний світ (метавсесвіт), у якому може отримувати однаково важливі для нього максимальні знання і досвід реального і штучного (синтетичного, на уявних моделях) світу, а також внутрішнього чуттєвого, оскільки системи чуття включені у когнітивний процес не тільки як пасивні «пристрої» отримання інформації про зовнішній світ, але й беруть безпосередню участь в управлінні отриманням знань шляхом формування когнітивної моделі життєдіяльності.

Подальші дослідження проблеми доцільно зосередити на вирішенні питання фізіологічної і ментальної «ціни» такого навчання. У цьому полі досліджень слід очікувати, скоріш за все, диференціації впливу мережі як такої і впливу віртуальної/доданої реальності (де фізіологічні механізми підключені до синтетичної діяльності безпосередньо). Для отримання практично цінних результатів потрібні більш широкі міждисциплінарні дослідження, які виходять за межі педагогіки і психології.

\section{СПИСОК ВИКОРИСТАНИХ ДЖЕРЕЛ}

[1] Encyclopedia of the Sciences of Learning. Seel, Norbert M., Ed. Springer US, 2012.

[2] В. Ю. Биков, "Інноваційний розвиток засобів і технологій систем відкритої освіти", 3б. наук. пр. : Сучасні інформаційні технології та інноваційні методики у підготовиі фахівиів: методологія, теорія, досвід, проблеми, вип. 29, с. 32-40, 2012.

[3] О. Ю. Буров, "Технології та інновації в діяльності людини ери інформації: людина та ІКТ", Інформаційні технології $і$ засоби навчання, № 6 (50), с. 1-13, 2015. [Електронний ресурс]. Доступно: http://journal.iitta.gov.ua/index.php/itlt/article/view/1317. Дата звернення: Січ. 10, 2016.

[4] О. П. Пінчук та ін., Організаџія та функиіонування мережі ресурсних иеентрів дистаниійної освіти загальноосвітніх навчальних закладів. Київ: Атіка, 2014.

[5] O. Burov, "Virtual Life and Activity: New Challenges for Human Factors/Ergonomics", in Symp. Beyond Time and Space STO-MP-HFM-231, STO NATO, 2014, pp. 8-1...8-8.

[6] NASA eEducation Roadmap (2005). Research Challenges in the Design of Persistent Immersiv Synthetic Environments for Education \& Training. [Online]. Available: /https://fas.org/programs/ltp/publications/NASA\%20eEducation\%20Roadmap.pdf.

[7] Blamire R. Digital Games for Learning. (2010, Nov.). Conclusions and recommendations from the IMAGINE project. European Schoolnet. [Online]. Available: www.imaginegames.eu.

[8] H. Lukosch, S. Kurapati, D. Groen, and A. Verbraeck, Microgames for Situated Learning: A Case Study in Interdependent Planning. Simulation \& Gaming. 2016. [Online]. Available: http://sagepub.com/journalsPermissions.nav.

[9] E. Ayiter, "Synthetic Worlds, Synthetic Strategies: Attaining Creativity in the Metaverse", in Metaplasticity in Virtual Worlds: Aesthetics and Semantic Concepts, 2011. [Online]. Available: http://www.igi-global.com/chapter/synthetic-worlds-synthetic-strategies/50385.

[10] "Synthetic Environments for HSI Application, Assessment, and Improvement", STO TECHNICAL REPORT TR-HFM-216. AC/323(HFM-216)TP/614, 2015.

[11] P. Blumschein, "Synthetic Learning Environment", in Encyclopedia of the Sciences of Learning. Springer US, pp 3256-3257, 2012.

[12] С. Г. Литвинова, "Компонентна модель хмаро орієнтованого навчального середовища загальноосвітнього навчального закладу", Науковий вісник. Серія: Педагогіка. Соиіальна робота, т. 35 , с. $99-107,2015$.

[13] О. П. Пінчук, "Результати експериментальних досліджень застосування мультимедійних технологій в навчальному процесі базової школи", Проблеми освіти: наук. зб., вип. 55, с. 41-50, 2008.

[14] "Synthetic Worlds: Emerging Technologies in Education and Economics", in Integrated Series in Information Systems, Andreas Hebbel-Seeger, Torsten Reiners, and Dennis Schäffer, Eds. Springer, vol. 33, 2014.

[15] O. Burov, and O. Tsarik, "Educational workload and its psychophysiological impact on student organism", Work, vol. 41, Suppl. 1, pp. 896-899, 2012.

[16] 2016 Learning Technology Study, 2016. [Online]. Available: https://www.docebo.com/elearning-lmsresources/papers-researches/. Accessed on: Jan. 10, 2017.

[17] А. И. Савенков, "Образовательная середа", Школьный психолог, № 19, с. 4-5, 2008. 
[18] Т. Н. Гущина, "Педагогическая сущность феномена «образовательная среда»: по материалам исследования", Научный журнал "Общество. Среда. Развитие (Terra Huтапа), вып. № 4, с. 187$190,2011$.

[19] В. Ю. Биков, "Теоретико-методологічні засади моделювання навчального середовища педагогічних систем відкритої освіти", Наукові записки. (Серія "Педагогічні науки"), Кіровоград : РВВ КДПУ ім. В. Винниченка, вип. 77, ч. 1, с. 3-12, 2008.

[20] J. A. Cannon-Bowers, and C. A. Bowers, "Synthetic learning environments", in Handbook of research on educational communications and technology, J. M. Spector, M. D. Merrill, J. van Merrienboer, and M. P. Driscoll, Eds. Mahwah: Lawrence Erlbaum, 2007, pp. 317-327.

[21] Richard E. Mayer, "Principles for multimedia learning with Richard E. Mayer". [Online]. Available: http://hilt.harvard.edu/blog/principles-multimedia-learning-richard-e-mayer.

[22] С. Ф. Сергеев, "Эргономика иммерсивных сред: методология, теория, практика", дис. д-ра наук, каф. эргоном. и инж. психолог. фак-т психолог. СПб гос. ун.-та, СПб, 2010.

[23] E. Castranova, "Exodus To The Virtual World: How Online Fun Is Changing Reality", 2007. [Online]. Available: https://rfmgjklo.files.wordpress.com/2017/06/best-0230607853-exodus-to-the-virtual-worldhow-online-fun-is-changing-reality.pdf.

[24] Julieta Aguilera, "The synthetic experience as an exoskeleton of the mind", Technoetic Arts, vol. 9, pp. 271-276(6), 2012.

[25] C. Aldrich, "Clark Aldrich's six criteria of an educational simulation". [Online]. Available: http://www.elearningguru.com/wpapers/sixcriteria.pdf.

[26] Stuart Brown, and Christopher Vaughan, Play: How it Shapes the Brain, Opens the Imagination, and Invigorates the Soul, Penguin, 2009.

[27] "Harnessing the power of video games for learning", in Nation. Sum. on Edu. Games, Washington, 2005. [Online].

Available: https://fas.org/programs/ltp/policy_and_publications/summit/Summit\%20on\%20Educational\%20Games. pdf.

[28] Edward Lavieri, "A Study of Adaptive Learning for Educational Game Design", ProQuest UMI. 2014.

[29] S. Lyvynova, and O. Burov, "Methods, Forms and Safety of Learning in Corporate Social Networks", in Proc. of the 13th Inter. Conf. on ICT in Education, Research and Industrial Applications. Integration, Harmonization and Knowledge Transfer, Kyiv, Ukraine, 2017, pp. 406-413.

[30] O. P. Pinckhuk, "Perspective analysis of use of social networks as learning tools in learning environment", Information Technologies and Learning Tools, no. 54 (4), pp. 83-98, 2016.

[31] O. Burov, "Life-Long Learning: Individual Abilities versus Environment and Means", in Proc. of the 12th Intern. Conf. on ICT in Education, Research and Industrial Applications. Integration, Harmonization and Knowledge Transfer, Kyiv, Ukraine, 2016, pp. 608-619.

Матеріал надійшов до редакиії 02.09.2017 p

\title{
СИНТЕТИЧЕСКАЯ ОБУЧАЮЩАЯ СРЕДА - ШАГ К НОВОМУ ОБРАЗОВАНИЮ
}

\author{
Пинчук Ольга Павловна \\ кандидат педагогических наук, старший научный сотрудник, \\ заместитель директора по научно-экспериментальной работе \\ Институт информационных технологий и средств обучения НАПН Украины, г. Киев, Украина \\ ORCID ID 0000-0002-2770-0838 \\ opinchuk100@gmail.com
}

\section{Литвинова Светлана Григорьевна}

доктор педагогических наук, старший научный сотрудник, заведующая отделом технологий открытой обучающей среды

Институт информационных технологий и средств обучения НАПН Украины, г. Киев, Украина ORCID ID 0000-0002-5450-6635

s.h.lytvynova@gmail.com

\section{Буров Александр Юрьевич}

доктор технических наук, ведущий научный сотрудник

Институт информационных технологий и средств обучения НАПН Украины, г. Киев, Украина ORCID ID 0000-0003-0733-1120

ayb@iitlt.gov.ua 


\begin{abstract}
Аннотация. В статье исследованы проблемы внедрения синтетической обучающей среды в практике образования. Проанализировано современные взгляды на сущность учебной среды и ее новые формы, основанные на информационно-коммуникационных технологиях. Особое внимание уделено кругу вопросов, которые объединяются в англоязычной литературе как «синтетическая среда», рассматриваемая в двух аспектах - как искусственная и как образующаяся благодаря синтезу реального физического мира и результатов симуляции и моделирования. Рассмотрены вопросы использования геймификации и моделирования как когнитивных технологий, а также социальных сетей как синтетической среды социального развития. Делается вывод о достижении синтетической учебной средой уровня субъекта обучения благодаря расширению ее содержательного и дидактического потенциала, трансформации личности как соискателя знаний в синтезирующий фактор учебного процесса.
\end{abstract}

Ключевые слова: синтетическая обучающая среда; искусственные среды; виртуализация; учебная деятельность; симуляция; моделирование; метавселенная.

\title{
SYNTHETIC EDUCATIONAL ENVIRONMENT - A FOOTPACE TO NEW EDUCATION
}

\author{
Olga P. Pinchuk \\ PhD (in Pedagogics), Senior Researcher, Deputy Director for Scientific Experimental Work \\ Institute of Information Technologies and Learning Tools of NAES of Ukraine, Kyiv, Ukraine \\ ORCID ID 0000-0002-2770-0838 \\ opinchuk100@gmail.com
}

Svitlana G. Lytvynova

Dr.Sc. (Edu), Senior Researcher, Head of the Department of Technologies of Open Learning Environment Institute of Information Technologies and Learning Tools of NAES of Ukraine, Kyiv, Ukraine ORCID ID 0000-0002-5450-6635

s.h.lytvynova@gmail.com

\section{Oleksandr Yu. Burov}

Dr.Sc. (Eng.), Leading Researcher

Institute of Information Technologies and Learning Tools of NAES of Ukraine, Kyiv, Ukraine

ORCID ID 0000-0003-0733-1120

ayb@iitlt.gov.ua

\begin{abstract}
The article studies the problems of introducing a synthetic learning environment in the practice of education. The modern views on the essence of the learning environment and its new forms based on information and communication technologies are analyzed. Particular attention is paid to a range of issues that are united in the English-language publications as a "synthetic environment", which is considered in two aspects - artificial environment and synthetic as is formed due to the synthesis of the real physical world and the results of simulation and modeling. There are considered issues of trends in usage of game-based learning and modeling as cognitive technologies, as well as of social networks as a synthetic environment of social development. Conclusions are drawn: synthetic learning environment becomes an independent subject of learning through the expansion of its content and didactic power, transformation of the individual as a recipient of knowledge into the synthesizing element of the educational process in the metaverse.
\end{abstract}

Keywords: synthetic learning environment; artificial environments; virtualization; educational activity; simulation; modeling; metaverse. 


\section{REFERENCES (TRANSLATED AND TRANSLITERATED)}

[1] Encyclopedia of the Sciences of Learning. Seel, Norbert M., Ed. Springer US, 2012 (in English).

[2] V.Iu. Bykov, "Innovation development of tools and technologies for eduction open systems", Suchasni informatsiini tekhnolohii ta innovatsiini metodyky u pidhotovtsi fakhivtsiv: metodolohiia, teoriia, dosvid, problemy: Zb.nauk. pr., vol. 29, p.32-40, 2012 (in Ukrainian).

[3] O. Iu. Burov, "Technology and innovation in human activity of the information age: human and ICT", Informatsiini tekhnolohii $i$ zasoby navchannia, № 6 (50), p. 1-13, 2015. [Online]. Available: http://journal.iitta.gov.ua/index.php/itlt/article/view/1317. Accessed on: Jan. 10, 2016 (in Ukrainian).

[4] O. P. Pinchuk et al., Organization and functioning of the network of resource centers of distance education for general educational institutions. Kyiv: Atika, 2014 (in Ukrainian).

[5] O. Burov, "Virtual Life and Activity: New Challenges for Human Factors/Ergonomics", in Symp. Beyond Time and Space STO-MP-HFM-231, STO NATO, 2014, pp. 8-1...8-8 (in English).

[6] NASA eEducation Roadmap (2005). Research Challenges in the Design of Persistent Immersiv Synthetic Environments for Education \& Training. [Online]. Available: /https://fas.org/programs/ltp/publications/NASA\%20eEducation\%20Roadmap.pdf (in English).

[7] Blamire R. Digital Games for Learning. (2010, Nov.). Conclusions and recommendations from the IMAGINE project. European Schoolnet. [Online]. Available: www.imaginegames.eu (in English).

[8] H. Lukosch, S. Kurapati, D. Groen, and A. Verbraeck, Microgames for Situated Learning: A Case Study in Interdependent Planning. Simulation \& Gaming. 2016. [Online]. Available: http://sagepub.com/journalsPermissions.nav (in English).

[9] E. Ayiter, "Synthetic Worlds, Synthetic Strategies: Attaining Creativity in the Metaverse", in Metaplasticity in Virtual Worlds: Aesthetics and Semantic Concepts, 2011. [Online]. Available: http://www.igi-global.com/chapter/synthetic-worlds-synthetic-strategies/50385 (in English).

[10] Synthetic Environments for HSI Application, Assessment, and Improvement", STO TECHNICAL REPORT TR-HFM-216. AC/323(HFM-216)TP/614, 2015 (in English).

[11] P. Blumschein, "Synthetic Learning Environment", in Encyclopedia of the Sciences of Learning. Springer US, pp 3256-3257, 2012 (in English).

[12] S. H. Lytvynova, "Component model of the cloud-based educational environment of a comprehensive educational institution", Naukovyi visnyk. Seriia: Pedahohika. Sotsialna robota, vol. 35, pp. 99-107, 2015 (in Ukrainian).

[13] O. P. Pinchuk, "Results of experimental research on the application of multimedia technologies in the basic school educational process", Problemy osvity: nauk. zb, iss. 55, pp. 41-50, 2008 (in Ukrainian).

[14] "Synthetic Worlds: Emerging Technologies in Education and Economics", in Integrated Series in Information Systems, Andreas Hebbel-Seeger, Torsten Reiners, and Dennis Schäffer, Eds. Springer, vol. 33, 2014 (in English).

[15] O. Burov, and O. Tsarik, "Educational workload and its psychophysiological impact on student organism", Work, vol. 41, Suppl. 1, pp. 896-899, 2012 (in English).

[16] 2016 Learning Technology Study, 2016. [Online]. Available: https://www.docebo.com/elearning-lmsresources/papers-researches/. Accessed on: Jan. 10, 2017 (in English).

[17] A. I. Savenkov, "Educational environment", Shkolnyi psykholoh, № 19, pp. 4-5, 2008 (in Russian).

[18] T. N. Hushchyna, "Pedagogical essence of the phenomenon "educational environment": based on research materials", Nauchnyi zhurnal "Obshchestvo. Sreda. Razvytye (Terra Humana), iss. № 4, pp. 187190, 2011 (in Russian).

[19] V. Yu. Bykov, "Theoretical and methodological principles of modeling the educational environment of educational systems in open education", Naukovi zapysky, (Seriia "Pedahohichni nauky"), Kirovohrad : RVV KDPU im. V. Vynnychenka, iss. 77, ch. 1, pp. 3-12, 2008 (in Ukrainian).

[20] J. A. Cannon-Bowers, and C. A. Bowers, "Synthetic learning environments", in Handbook of research on educational communications and technology, J. M. Spector, M. D. Merrill, J. van Merrienboer, and M. P. Driscoll, Eds. Mahwah: Lawrence Erlbaum, 2007, pp. 317-327 (in English).

[21] Richard E. Mayer, "Principles for multimedia learning with Richard E. Mayer". [Online]. Available: http://hilt.harvard.edu/blog/principles-multimedia-learning-richard-e-mayer (in English).

[22] S. F. Serheev, "Ergonomics of immersive environments: methodology, theory, practice", dis. d-ra nauk. kaf. ergonom. i inzh. psikholog. fak-t psikholog. St. P gos. un.-ta. St. P. 2010 (in Russian).

[23] E. Castranova, "Exodus To The Virtual World: How Online Fun Is Changing Reality", 2007. [Online]. Available: https://rfmgjklo.files.wordpress.com/2017/06/best-0230607853-exodus-to-the-virtual-worldhow-online-fun-is-changing-reality.pdf (in English).

[24] Julieta Aguilera, "The synthetic experience as an exoskeleton of the mind", Technoetic Arts, vol. 9, pp. 271-276(6), 2012 (in English). 
[25] C. Aldrich, "Clark Aldrich's six criteria of an educational simulation". [Online]. Available: http://www.elearningguru.com/wpapers/sixcriteria.pdf (in English).

[26] Stuart Brown, and Christopher Vaughan, Play: How it Shapes the Brain, Opens the Imagination, and Invigorates the Soul, Penguin, 2009 (in English).

[27] "Harnessing the power of video games for learning", in Nation. Sum. on Edu. Games, Washington, 2005. [Online].

Available: https://fas.org/programs/ltp/policy_and_publications/summit/Summit\%20on\%20Educational\%20Games. pdf (in English).

[28] Edward Lavieri, "A Study of Adaptive Learning for Educational Game Design", ProQuest UMI. 2014 (in English).

[29] S. Lyvynova, and O. Burov, "Methods, Forms and Safety of Learning in Corporate Social Networks", in Proc. of the 13th Inter. Conf. on ICT in Education, Research and Industrial Applications. Integration, Harmonization and Knowledge Transfer, Kyiv, Ukraine, 2017, pp. 406-413 (in English).

[30] O. P. Pinckhuk, "Perspective analysis of use of social networks as learning tools in learning environment", Information Technologies and Learning Tools, no. 54 (4), pp. 83-98, 2016 (in English).

[31] O. Burov, "Life-Long Learning: Individual Abilities versus Environment and Means", in Proc. of the 12th Intern. Conf. on ICT in Education, Research and Industrial Applications. Integration, Harmonization and Knowledge Transfer, Kyiv, Ukraine, 2016, pp. 608-619 (in English). 